\title{
SCRUM AND AGILITY BEYOND IT: EVIDENCES IN THE BRAZILIAN MINING INDUSTRY
}

\author{
SCRUM E AGILIDADE ALÉM DELE: \\ EVIDÊNCIAS NA INDÚSTRIA DE MINERAÇÃO BRASILEIRA
}

\author{
Mohamad Ismat Soueid \\ Mestre em Administração \\ Fundação Instituto de Administração - FIA \\ São Paulo, SP - Brasil. \\ mohamad.soueid@faculdadefia.edu.br \\ Antonio Felipe Corá Martins \\ Mestre em Administração \\ Faculdade Metropolitanas Unidas - FMU \\ São Paulo - SP - Brasil. \\ antoniofelipecora@gmail.com
}

\section{Abstract}

\begin{abstract}
According to the 14th State of Agile Report (Versionone, 2020) Agile Project Management (APM) provides positive results for improvement in productivity, alignment, visibility and prioritization of demands. Although it is applied in the software development industry, other sectors seek its adoption in order to obtain the results known by the methodology, such as in the financial, sales, marketing and industry segments. Through a qualitative approach, the present work aimed to understand how the values of the Agile Manifesto and scrum tools could generate positive efficiency results in the routine of a Brazilian mining industry, which was completely unaware of the APM and presented management failures. As a research protocol, the intervention occurred through a training and training program (face-to-face) with 14 employees of the organization from various areas, in which the variation in efficiency gain after the application of APM in the routine was measured. As results, it was possible to observe that there were positive variations in the relationship between people (collaboration), greater proximity of the customer in the process of delivering values (perception of product value), better communication and interactivity between team members, better prioritization of tasks (feasibility), generation of new products (innovation) and the adoption of a retrospective meeting at the end of each delivery cycle as a formal procedure of continuous improvement.
\end{abstract}

Keywords: Agility. Scrum. Mining industry. Agile.

\section{Resumo}

De acordo com o $14^{\circ}$ Relatório do Estado do Agile (Versionone, 2020), a Gestão de Projetos Ágeis (GPA) apresenta resultados positivos para melhoria da produtividade, alinhamento, visibilidade e priorização das demandas. Embora seja aplicada na indústria de desenvolvimento de software, outros setores buscam sua adoção a fim de obter os resultados conhecidos pela metodologia, como nos segmentos financeiro, comercial, marketing e industrial. Por meio de uma abordagem qualitativa, o presente artigo teve como objetivo compreender como os valores do Manifesto Ágil e das ferramentas scrum poderiam gerar resultados positivos de eficiência na rotina de uma indústria de mineração brasileira, que desconhecia completamente a GPA e apresentava falhas de gestão. Como protocolo de pesquisa, a intervenção ocorreu por meio de um programa de treinamento (presencial) com 14 funcionários da organização de diversas áreas, no qual foi medida a variação do ganho de eficiência após a aplicação da GPA na rotina. Como resultados, foi possível observar que houve variações positivas no relacionamento entre as pessoas (colaboração), maior proximidade do cliente no processo 
de entrega de valores (percepção do valor do produto), melhor comunicação e interatividade entre os membros da equipe, melhor priorização de tarefas (viabilidade), geração de novos produtos (inovação) e adoção de uma reunião retrospectiva ao final de cada ciclo de entrega como procedimento formal de melhoria contínua.

Palavras-chave: Agilidade. Scrum. Industria de mineração. Ágil.

\section{Cite como - American Psychological Association (APA)}

Soueid, M. I., \& Martins, A. F. C. (2021, Ed. Esp. jan./abr.). Scrum and agility beyond it: evidences in the brazilian mining industry. Revista de Gestao e Projetos (GeP), 12(1), 123148. https://doi.org/10.5585/gep.v12i1.17624.

\section{Introduction}

Although project management is one of the disciplines increasingly used in the world (Rad \& Raghavan, 2000), capable of carrying out organizational planning in the sense of implementing the strategies of organizations, there is still a high occurrence of failures and problems in projects developed in various segments, especially due to the lack of standardization of processes, efficiency and adoption of basic elements in the triple restriction of projects, that is, in the scope, costs and time of the project (Buchanan, 2008).

According to PMBOK (PMI, 2017), managing projects means applying knowledge, skills, tools and techniques to the project in order to meet its requirements. Until the 1990s, project managers in the software development industry used management techniques for projects with predetermined or traditional life cycle (when the scope, time and costs required to deliver value are determined as early as possible), generating conflicts in development, since there is difficulty in knowing initially all the points and needs for this type of product. Thus, they began to redesign the frameworks far known to obtain greater dynamism and flexibility of the scope (Vacari, 2015), achieving the so-called light methods, later known as Agile Project Management (APM). Thereby they developed a new classification for the life cycles of the projects: the iterative and incremental (when there is purposeful repetition of the phases of the project to increase the understanding of their requirements as the activities take place in their development).

From then on the APM consolidated to understand techniques, skills and tools that aimed to meet complex projects, with high cost of change and future uncertainties, such as Extreme Programming (XP), Lean Software Development, Crystal Method, Resource Oriented Development (Dingsøyr, Nerur \& Balijepally, 2012), which culminated in the Agile Manifesto (Beck et. al., 2001). Scrum is among the most used APM tools and 
techniques, used by $58 \%$ of project managers (VERSION ONE, 2020).

During the 2000s, APM gained more and more space in various segments of the economy, especially for providing a simpler, more practical and flexible management logic in the face of uncertainties (Amaral et. al., 2011). Thus, APM are positively associated with projects in which life cycle is oriented to the effective delivery of the product to the detriment of the management bureaucracy (PMI, 2017), and can be adopted by organizations outside the software development industry, including sectors of traditional organizations that require more flexible management to innovate (Conforto et. al., 2014).

This expansion in the adoption of APM, according to Baccarini (1996), occurred due to the increase in variables and interdependencies in products, generating proportionally greater complexity to the projects, which, according to this author, causes the difficulty in applying the traditional approach (for predetermined cycles) for all projects.

However, although there is a considerable amount of research and evidence on implementations of Scrum and APM principles in software industry environments, few empirical studies can be found in other sectors, especially the Mining industry. In a survey conducted in the EBSCO database (2020), when searching for "agile project management" 445 results are found between
2004 and 2020, and when associating this search with "software development" 137 (between 2004 and 2020) are found and for the search with "mining industry " no relevant results are found.

The selected analysis unit (Celta Brazil) is a typical medium-sized industry in the mining sector. With its head office in the city of São Paulo and customers on a global scale. It has suppliers in Cuba, Turkey and Slovakia; it has approximately 45 direct employees and average revenue of US $\$ 14$ million per year with an average growth of $30 \%$ per year. Its main activity aims at the extraction and treatment of a specific ore (Zeolite) which is intended for the treatment of water, animal nutrition, agriculture and various inputs (such as detergents and asphalt). The main challenge encountered by the organization was to provide the management of the change of its projects due to the need to innovate in its activities and increase its market share. Due to a strong hierarchy into the organization the communication was not effective and often the products generated have not reached the results expected by the company's board of directors. These challenges generated severe difficulties in the management of its projects, which consequently prevented the company from achieving its objectives, such as obtaining a larger share of the market, greater penetration in specific sectors of the industry and staying ahead of the competition. 
In face of this scenario one question of research has risen: how can APM improve project management and the results of an organization that does not belong to the software development industry? In this sense, the main objective of this study is to understand how the values of the Agile Manifesto and Scrum tools were able to generate positive efficiency results in the routine of a Brazilian mining industry, which was completely unaware of the APM and, at the same time, presented management failures, which prevented it from achieving its market objectives.

Through the CIMO (Context, Intervention, Mechanisms and Results Obtained) method (Biancolino et. al., 2012), the authors of this research worked as instructors of the Scrum training program and the principles contained in the Agile Manifesto (covering all the content for Scrum.org the Scrum Master Professional Exam 1), going through the four stages of the method: contextualization of the problem situation, intervention to correct the problem, description of the mechanisms for solution and results obtained.

This paper is organized as follows: in addition to Section 1 (introduction), section 2 presents the theoretical basis for Agile Project Management (APM) and the tools of the Scrum methodology. Section 3 details the CIMO methodology (Biancolino et. al., 2012) applied. In section 4, the results are presented and discussed. Section 5 contains the findings and suggestions for future studies. Section 6 and last contains the references.

\section{Theoretical framework}

In this section, the theoretical bases will be presented that fundamentals for the development of this work.

\subsection{Origins of Agile Methods}

Agile innovation is one of the buzzwords of our times and this has a reason to be. The 14th Annual State of Agile Report (VERSIONONE, 2020) points out that the main gain of an organization that uses APM is the adaptability to frequent market changes being able to improve the management of priorities, increasing productivity and product quality, reducing risks and impediments, greater visibility with stakeholders, customers and project members and greater moral sense of responsibility.

Despite its strong application from the 2000s, popularized among software development projects, APM dates back to the industrial process Deming (1951), in the 1920s to 1930 of the twentieth century (Werkema, 1995). In the 1950s, Gerald M. Weinberg, IBM computer scientist and Mercury project manager stated that his project division in federal systems located in Los Angeles was working on a cyclical model of incremental deliveries, which caused radical changes in project delivery at the time by deprecating the 
classic predetermined cycle model (Larman \& Basili, 2003).

In 1961, in the face of the great technological advances of the post-war period, Drucker (1992) began to consider that the successor of the factory workers would be the knowledge worker, suggesting a systemic view of the administration, associated with the characteristics of innovation and flexibility of organizations in the new world economy (Catelli \& Santos, 2001).

Thus, considering this more holistic view of the organization (proposed by Drucker), allied to the PDCA cycle of Shewhart-Deming, that Taiichi Ohno in 1978, along with the family owning the company Toyota (Eiji Toyoda) created the so-called Kanban System Materialization of Just-in-time (Maximiano, 2018). The Toyota production system, according to Ohno (1997), aims to work in a highly adaptive regime to the reality of each company, informing that the development of products rarely happens in a linear and static way, but rather by a dynamic and iterate process of trial and error.

From the consolidation of these studies, the first proposal on Scrum was disseminated by Nonaka and Takeuchi (1986), in which they noticed the high efficiency of small and better performing teams in some companies surveyed (such as Xerox, Honda, Yamaha, Black \& Decker, Brother and IBM), to the detriment of linear deliveries and large groups or departments of production management. From a rugby play they realized that small teams (Scrum) focused on a single task (replacement of the ball in play) and multidisciplinary (players of all positions) would have higher productivity generating better results.

It was from then on that the software development industry appropriated such concepts, tools, techniques and skills to redesign the linear approach to product development on IT (Sliger \& Broderick, 2008). It was in 1993 based on the entire Scrum framework (Nonanka and Takeuchi, 1986), founded on Ohno's Toyota production system (originally from 1978) and Stewhart-Deming's PDCA cycle (1920s and 1930s) that project managers Jeff Sutherland, John Scumniotales and Jeff McKenna documented and implemented project management for software development via Agile Methodology at Easel Corporation (Sutherland, 2004). Since then, other projects have started to use this logic. A consortium of Canadian companies built their air traffic control through incremental deliveries of new software for management (Kruchten, 1996). At Chrysler-C3, Beck (1999) participated in the company's payroll improvement project, whose goal was to unify four antagonistic global software systems, which held 86,000 employees, applying the first concepts of Extreme Programming (XP).

In 2001 MacCormack published a study pointing out the key factors in the project development cycle by APM, concluding that, after analysis of the projects selected during the 1990s, project APM results in high-quality 
products and processes. For such reasons as in the same year of 2001, a group of 17 experts in the area of project management in software development, consolidating the learning obtained in the practices of Scrum, Extreme Programming and other iterative-incremental projects, in order to promote the values and principles of Agile Methodologies, published the Agile Manifesto. On it, the following items were exposed by core values of the Agile Methodology of Project Management (Beck et. al., 2001), thus considering that there are more values to the items on the left, without failing to the items on the right, according to the Table

Table 1 - Values of Agile Methodologies of project management

\begin{tabular}{|c|c|c|c|}
\hline & Core values & & Relevant values \\
\hline 1. & Individuals and interactions & more than & processes and tools \\
\hline 2. & Software in operation & more than & comprehensive documentation \\
\hline 3. & Customer collaboration & more than & negotiation of contracts \\
\hline 4. & Respond to changes & more than & follow a plan \\
\hline
\end{tabular}

Source: Agile Manifesto (Beck et. al., 2001).

As it can be seen from the 1920s with the cyclical model of Shewhart-Deming (1951) until the publication of the Agile Manifesto at the beginning of the $21 \mathrm{st}$ century, it is recognized that project management has become increasingly complex to absorb all these dimensions of the quality of what is being delivered. This has generated major changes in the way products are designed, changes in product appearance, work teams with greater autonomy and interdependence between areas (cross-functions), lean production systems and pressure for faster deliveries, with low inventories and technology adoption (Correia \& Correia, 2012).

\subsection{Differences between APM and the traditional approach}

The classic project management model, that is, project management by predetermined cycle (cascade), aims to manage projects or products that are well defined and known by those involved, since they want to obtain, in advance, the largest amount of data for after starting the execution and delivery of value, according to the PMBOK Guide (PMI, 2017). On the other hand, APM practices are more likely to be applied in projects and products where there are difficulties in predicting points in advance, especially highly dynamic products and inserted in constant changes (Sutherland \& Schwaber, 2017).

In this sense it is observed that there is an essential counterpoint between APM and traditional (or predetermined) project management: the scope of the project. The Figure 1 demonstrates how each methodology 
sees the points of the triad of project

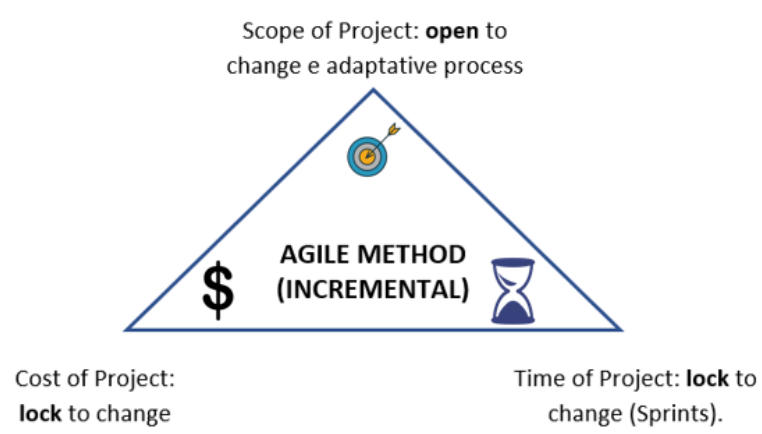

Figure 1. Triad of project management (scope, cost and time) Source: adapted by the authors from Sliger and Broderick (2008).

Both logics are based on the triad of project management: time, cost and scope. While in the case of predetermined management the scope is well defined and rigid, the management by APM confers rigor in time and cost, leaving the scope free to admit and absorb changes in the process (Sliger \& Broderick, 2008).

Therefore, according to the PMI (2017), it is possible to affirm that the more predictable the project is, it is natural that there are loss costs and control of time, because in order to achieve all the requirements raised to generate the product, all necessary efforts are undertaken, as initially known, while the more complex the project is, its scope must meet the volatility of changes, setting the time limit until reaching the "ideal" point of desire of the stakeholder, applying a certain cost to reach this point, working cyclically to increase the understanding of complexity, with a view to achieving the agreed delivery and defined as "ideal" (iterative-incremental cycle). Through this comprehension that Highsmith (2002) differentiates the concept of "speed" of management.

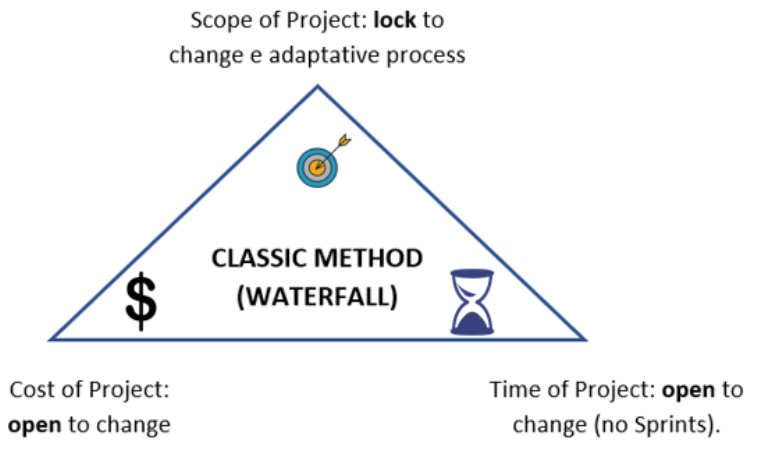

Scope of Project: lock to

e adaptative process

open to change

"effectiveness" in APM, as the ability to balance flexibility and stability, despite the difficulties inherent to the implementation of this method of project management.

In recent years, several researchers have improved the state-of-the-art on the subject, adopting APM for several projects of the software development industry: methods for web accessibility (Sanchez-Gordón \& Luján-Mora, 2017); cost-benefit ratio in the use of APM (Bai, Mork \& Stray, 2017); application of APM for the development of educational and inclusive software's (Tiangtae, et al., 2017); studies on delivering high quality products in the agile environment (Balasubramani, et al., 2016); and comparative academic productions between the benefits of APM with traditional methods (Alahyari, Berntsson Svensson \& Gorschek, 2017; Rodriguez, Mendes \& Turhan, 2018; Sambinelli \& Borges, 2019).

On the other hand, recent studies show that it is possible to reconcile the practices of PMBOK (PMI, 2017) to Scrum (Sutherland \& Schwaber, 2017) in which the organization 
can obtain "benefits of the two methodologies within a single tool making the progress of the project much safer" (Moraes \& Ricco, 2020).

\subsection{Scrum: Key aspects}

Considering that the APM initially constituted as a set of tools and techniques to manage interactive-incremental cycle projects, Scrum is the main tool to be adopted by project managers (VERSION ONE, 2020). Scrum is a special way for teams to work together and develop a product, delivering it in small parts (Cardozo et. al., 2010). In other words, it is a construction process where a piece is built on the previous parts. A small part is completed each time. This fosters creativity and gives teams room to respond to feedback and change. Scrum can also be a framework for effective teamwork in complex contexts, which provides a small set of rules designed to create enough structure for teams to focus on (Amaral et. al. 2011). A structure, or skeleton, is considered the basic structure and serves as a support and guide for the construction of something from the expansion of this structure itself. In other words, it is a conjunction of concepts used to solve a problem of a specific domain (Sabbagh, 2014).

According to Eder, Conforto, Amaral and Silva (2015), Scrum consists of scrum teams, events, artifacts and rules. Rules are essential for joining teams, events, and artifacts during the project. They also provide a nice framework for resolving conflicts within a project. Scrum uses a lean "Pull" technique to improve flow through the system and avoid overload (Liker \& Meier, 2007). This traction system resides primarily in the Sprint Planning process where the team is enabled for only the amount of work it can reasonably complete within the Sprint. During the Sprint the team is expected to be responsible for all the work to turn the plan into a delivered product (Sutherland \& Schwaber, 2017).

In addition, Scrum implements a process to reduce or even eliminate wastes (Ohno, 1997). A Scrum team is encouraged to identify their own impediments. When they cannot remove their own impediments, Scrum Master works on it to eliminate them in priority order. These impediments can be categorized into various types of challenges, but waste, in many ways, is the most common. This endless quest for perfection through waste removal is part of the Kaizen philosophy (Liker, 2004).

Scrum is based on an interactive and incremental project management structure with the aim of controlling risk and optimizing predictability, containing three pillars (Sutherland \& Schwaber, 2017):

- Transparency: The process should be understandable and visible to all involved;

- Inspection: The Scrum team should inspect Scrum artifacts frequently to detect problems as quickly as possible; 
- Adaptation: If an inspection shows that some aspects of the project are not acceptable or outside the scope of the project, the process can be adjusted to maximize value.

Also according to the Scrum Guide (Sutherland \& Schwaber, 2017), the Scrum team consists of a Product Owner, a Scrum Master and a Development Team. The teams are self-organized, self-managed and interfunctional. They have to take control of the project, especially the Sprint plan, and have all the skills and tools needed to achieve the goals without relying on people outside the team. The team delivers products incrementally and iteratively, in order to maximize the value of feedback received.

Scrum Master ensures that Scrum keeps happening. In his role he trains the team to maintain the teams of events, facilitates when there are doubts and also keeps log and removes the impediments of the team. He can also work with other Scrum Masters to improve the use of Scrum in the organization. The Product owner is responsible for managing the Product Backlog, product requirements, and his ultimate goal is to maximize the value of the development team through a prioritized backlog management. The Development Team is responsible for delivering a release product at the end of each "Sprint", which is a maximum period, also called a time box, to create a usable product increment. Development Team members manage their own work and have no subthemes. The team size is an important aspect because very small teams may not have all the skills and workforce to deliver a product usable by sprint, on the other hand, very large teams grow in complexity and are difficult to be self-managed (Camargo \& Galegale, 2020).

In Scrum, the events are time box, which means that the event ends when it reaches its maximum duration. Scrum events are designed to inspect artifacts and adapt new methods to solve problems and opportunities encountered during work. The objectives of the events are to increase transparency, adaptation and inspection in the development process.

Sprint is the heart of Scrum (Sutherland \& Schwaber, 2017). It is a time box to create a used and finished product. Each Sprint is part of the project with a plan of what needs to be built and how it needs to be built. Sprints can last between one and four weeks. Each sprint has a goal, which should not be changed during the Sprint because the Product Owner can cancel sprints if there is any change in relation to technology, opportunities and market needs or even in the direction of the company. The Figure 2 shows the Scrum Framework overview. 


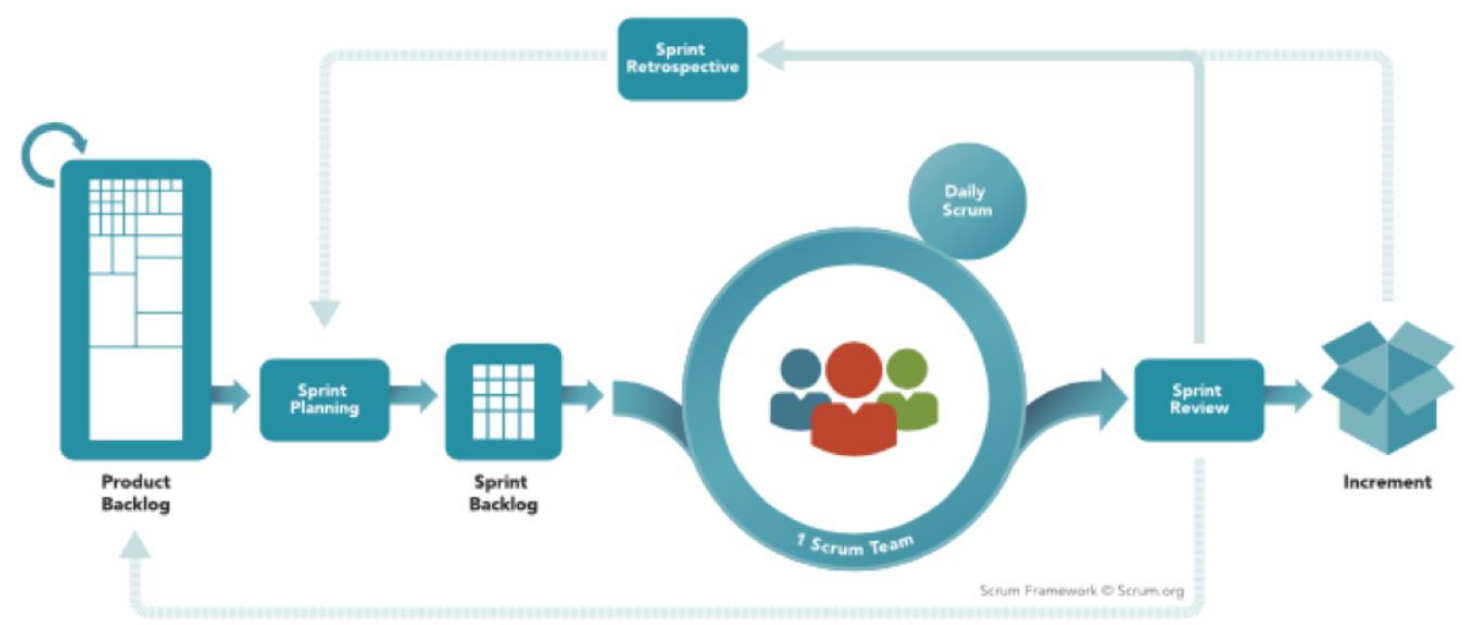

Figure 2. The Scrum Framework

Source: Sutherland \& Schwaber, 2017.

The Scrum team plans the goals of each Sprint, along with the products and how they will be delivered, at the Sprint Planning Meeting. Each sprint needs to create a usable and potentially reasonable product, also called a "Done" product. Scrum team members must come to a common understanding of what constitutes a "Done" product, as this definition may vary within the requirements of the organization and team. The duration of the Sprint Planning Meeting is of eight hours for a four-week sprint and proportionally shorter for shorter races.

In addition to Sprint Planning, there is a 15 minutes daily meeting called Daily Scrum. In this meeting, team members update each other about their progress from the last meeting up to date, their goals for the next meeting, and impediments and the difficulties they are facing. This meeting has a time box of 15 minutes, regardless of the length of the sprint, it is always 15 minutes.
At the end of each Sprint there are 2 meetings: a Sprint Review and a Sprint Retrospective. The Review is a product demonstration for the Product Owner and or stakeholders. It's the time for the team to show the work done during the sprint and collect feedback. Retrospective is an internal team meeting to identify opportunities to improve its own work. It is highly linked to the concept of continuous improvement.

Scrum artifacts are the Product Backlog, Sprint Backlog, Definition of "Done" and Product Increment, which is the sum of the Product Backlog, and the sprint backlog, completed items in all Sprints. The Product Backlog contains the features, requirements and expectations of the product. It shows the product from a technical and business point of view. The Product Owner is responsible for managing the product backlog, including prioritization, maintenance and clarity. The product backlog is a living artifact and should 
continue to evolve as long as there is a product.

The Sprint Backlog is the list and plan for the Product Backlog items that are selected to be transformed into a "Done" product for the current Sprint. The Development Team can clarify any details about the items with the Product Owner.

The Definition of Done contains all the work required for an increment that can be considered done. This can include functional or non-functional requirements, for example, a business process that looks for bugs or a performance evaluation for the item. As noted, the Scrum framework is the result of the historical evolutionary process of the project management concept, which originated based on the adaptation to the complexity imposed on management of projects.

\section{Methodological procedures}

For the general analysis of organizational systems, considering cultural criteria and operating processes, there is a need to understand the scenario instead of just analyzing sources and data as isolated parts. According to Nielsen et al. (2011) it is recommended that the researcher formally declares his epistemological line in order to complement and justify the use of hypotheses and/or formal propositions, thus considering his vision of science. In this sense, this study is classified as exploratory in terms of its objectives, qualitative as to the nature, single case regarding the object of study, questionnaire and semi-structured interviews regarding the technique of data collection, and triangulation regarding the analysis of the data obtained (Gil, 2008).

As an elaboration method, this study used the logic protocol "CIMO" (Biancolino et. al., 2012) to construct technical reports in project management for professional master's degrees (Context, Intervention, Mechanisms and Results Obtained).

The study was applied in 3 major stages between October 2019 and January 2020. In the first phase, 14 employees of the governing body from the company Celta Brazil were selected. These 14 participants were selected because they held key or leadership positions in each of the areas of the organization (marketing, financial, supply chain, production, human resources and management), which could promote the maintenance of learned content (APM), as well as disseminate to other employees. The data has been collected through open interviews and a structured questionnaire, via Google Forms, containing 13 quantitative questions, whereas 8 questions in 10 Likert points (from 1 to 10 ), and 5 questions with binary answers. The objective of this questionnaire was to understand the level of application of existing Scrum values, roles, artifacts and events, although the team has never had previous contact with the logic and the agile processes. The questionnaire at the beginning was needed to compare another round of the same 
questionnaire at the end of the process, to analyse the level of evolution or not of the application of APM in the organizationin the organization. The objective of open interviews was to know about main aspects of the organization and the project management process, all performed in person, recorded and transcribed, on the dates shown in Figure 3, using the questionnaire in annex 1 as a script.

It is emphasized that to obtain the general data that formed the context of the problem situation, employees linked to senior management (such as managers and directors) belonging to all areas of the company (marketing, supply chain, human resources, finance, engineering, sales and $R \& D$ ) were selected, including the CEO.

The Likert scale used (from 1 to 10 points) is very similar to the classification model of elementary schooling, which justifies the choice of capturing the influence of scrum of the perception of participants between classes and workshops of the theme, revealing a greater familiarity with the classification of the questions. In addition, the other 05 questions used the simple binary model (yes or no), for objective questions such as "Scrum Events", "Prioritize Tasks" and "Scrum Team" as means to simplify data collection and routine association before and after scrum implementation. Phase 01 aimed to support the construction of the problem-situation context (Annex 01 and 02).

In the second phase an educational program was applied on which the origins and concepts of Scrum and forms of its application in the daily life of the company were explained in a practical way. Everything with the intention of promoting the most applicable solutions based on the previous diagnosis. Importantly note, the application of the educational program is considered an intervention, because it was used to solve the problem presented by the analysis unit. The program consisted of 12 hours of course divided into 3 days of 4 hours. This second phase started from the concepts obtained in phase 01, including to foster intervention. That is, phase 2 (application of the learning program on Scrum) was the intervention and the mechanisms adopted to solve the points of the problem situation in the selected unit of analysis (Annex 01 and 03).

The third phase occurred after the completion of the educational program in which the same structured questionnaire was made available again. This allowed the researchers to compare, via classification system and implicit perceptions, the variation of the application and influence of Scrum in the day-to-day routine of the company. The likert scale data compilation was made through the SPSS software in version 15.0. From the data, corresponding to the 14 participants, a descriptive statistical analysis was generated containing the average, percentages, standard deviation, upper and lower values of each category. This data was also used to create radar charts. In turn, data graphs were generated for binary fields (yes or no), charts 
that present the percentage of answers to each consolidated question in tables to measure the level of perception before and after the Scrum program. The third phase allows us to understand how much of the learning obtained in the Scrum training and application program was effective in the organization's routine, focusing on the solution and obtaining the results for repairing of the points contained into the problem situation. Figure 3 shows the CIMO cycle used in the unit of analysis of this study.

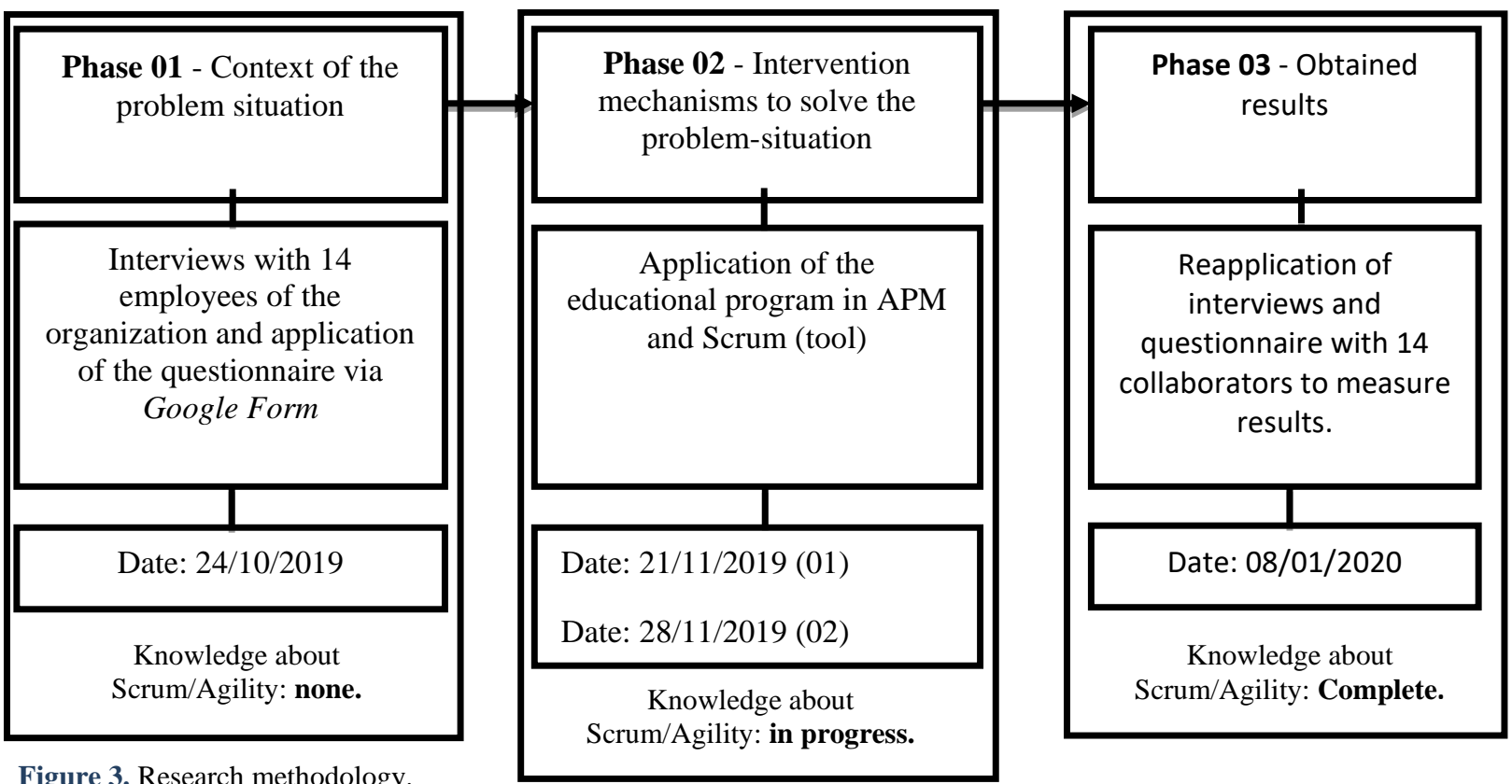

Source: Prepared by the authors based on Biancolino et al. (2012).

Considering the script exposed in this study, which justifies this research, the analysis and discussion of the data follows hereafter.

\section{Analysis and data discussion}

In this section the findings obtained through the analysis of the answers in both questionnaires and separate interviews are discussed in two parts: in relation to the generic values and criteria (Likert scale) and on the Scrum tools in detail (binary question data), demonstrating the points of the problem situation, the interventions and their mechanisms and results obtained.

\subsection{Description of the problem situation}

The organization selected in this study is a medium-sized mining industry based in the city of São Paulo. As its main activity the company extracts a specific type of ore (Zeolite) and after a chemical treatment process, confers specific destinations for various circumstances: agriculture, animal nutrition, polymers, paints, water treatment and asphalt mixture. The organization's projects are managed in a decentralized manner, with teams allocated in different objectives (one for each productive segment). The leadership encourages teamwork and 
promotes a productivity-friendly work environment but faces some resistance.

In interviews with 14 employees from all areas of the organization, on October 24, 2019, some points were unanimous amongst all: there is low communication between project teams, low relationship with customers (even if B2B), high possibility of frustration among project members for resistance to changes in projects, difficulty in implementing the strategy in the tactical and operational scope, projects do not meet deadlines, and difficulties in organizing and prioritizing tasks.

Based on these problems the leadership tried to promote a change in the way projects are managed: it began to focus on processes rather than the focus on department. However, it did not have the knowledge to apply methodologies and tools to support this change. It was then that the possibility arose to try to apply elements, values, principles, techniques, or tools of the APM to support this change, based on studies and reports that indicated a certain success in the deficient criteria of the organization.

\subsection{Mechanisms and proposal for intervention}

Given the challenges faced by the organization in the way of managing its projects, it was decided by the leadership to promote training and a training program for the 14 employees in the areas of the company, so that they could learn about APM. Therefore, a cycle of interactive lectures was created: on November 21, 2019, the introduction to the
Agile Manifesto and the general Scrum processes; on November 28, 2019, the practical application of concepts in new projects of the organization, defining roles (Scrum Master, Time Development and Product Owner), with theoretical application of ceremonies and artifacts of Scrum, and on December 5, 2019, end of the training cycle and general doubts.

The questionnaire contained in Annex 01 was applied on October 24, 2020 (on the same day of the interviews to harvest the context of the problem situation), to measure the level of proximity of existing practices, although unaware of the APM and its reapplication on January 8, 2020, with the return of the interviews with the same 14 employees. This repetition of the questionnaire and interviews with the participants of the experiment before and after knowing more about the APM was the criteria used by the researchers as a comparative method of evolution in the use of APM, at the same time that the Authors of this research also applied the training and the training program during the month of November, 2020.

\subsection{Results obtained}

First it is important to note that the Figure 4 demonstrates the level of knowledge of Scrum that the participants had prior to the training program on October 24, 2019. 


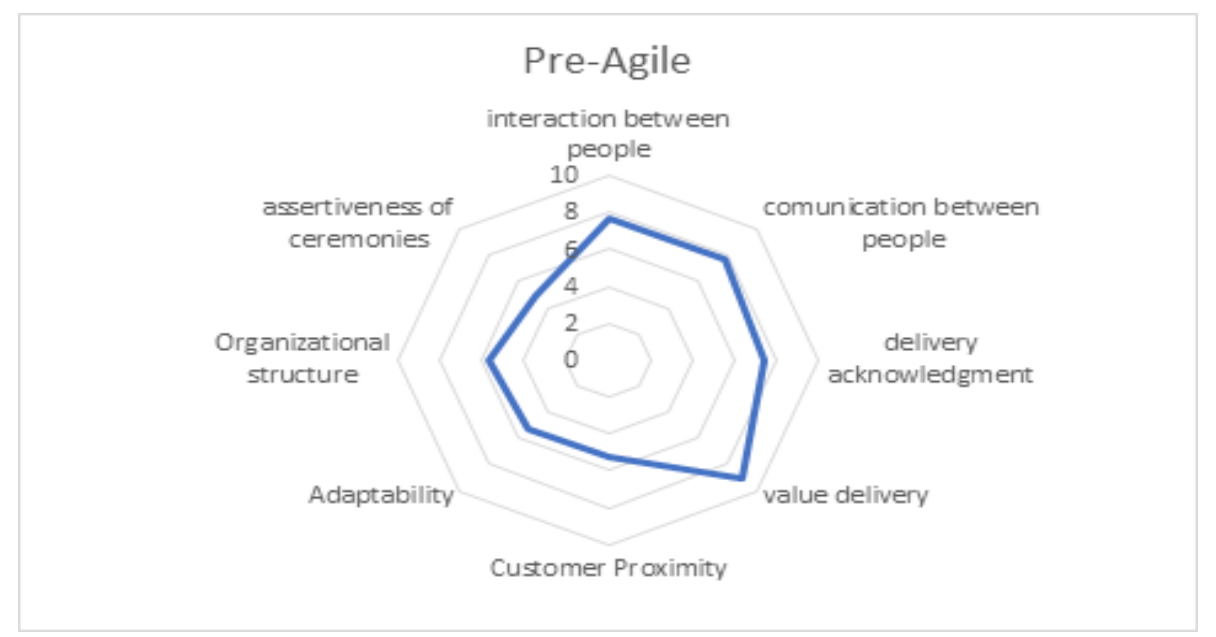

Figure 4. Knowledge about Scrum before the training program

Source: Researchers (Excel).

It is noteworthy that even before knowing the values of the Agile Manifesto, especially with regards to the effective delivery of values, the unit of analysis was already very aware of it, comparable to what the Agile Manifesto names as "Software working on comprehensive documentation". It is also possible to note that the levels of relationship, interaction and communication between the team are high-level, demonstrating contrast with how much alleged about low communication between people and their interactions in the workplace.

On the other hand, the level of adaptability ("Responding to change when following a plan") is low, which can be explained by the fact that it is a mining company, working with well-defined and predictive engineering processes, which reflects in the repeated information of the interviews regarding the high occurrence of frustration of people when the project changes its course suddenly.
However, the data that most draw attention are the low level of perception regarding the effectiveness of meetings (assertiveness of events) and customer participation in development processes (customer proximity). It can be said that communication between people is high given the team spirit and mutual collaboration, but in an ineffective way once it is lost in the face of bureaucracies and failures in management, while the interviews were revealing when pointing out that the teams act in fiefdoms or silos, almost as family units, which stimulates the dispute and feud between the teams, but strong link and moral sense in the internal relationship. On the other hand, after the learning process and the effective application of Agile Manifesto values and Scrum process tools, there were substantial increases in some of the areas analyzed, as shown in the Figure 5. 


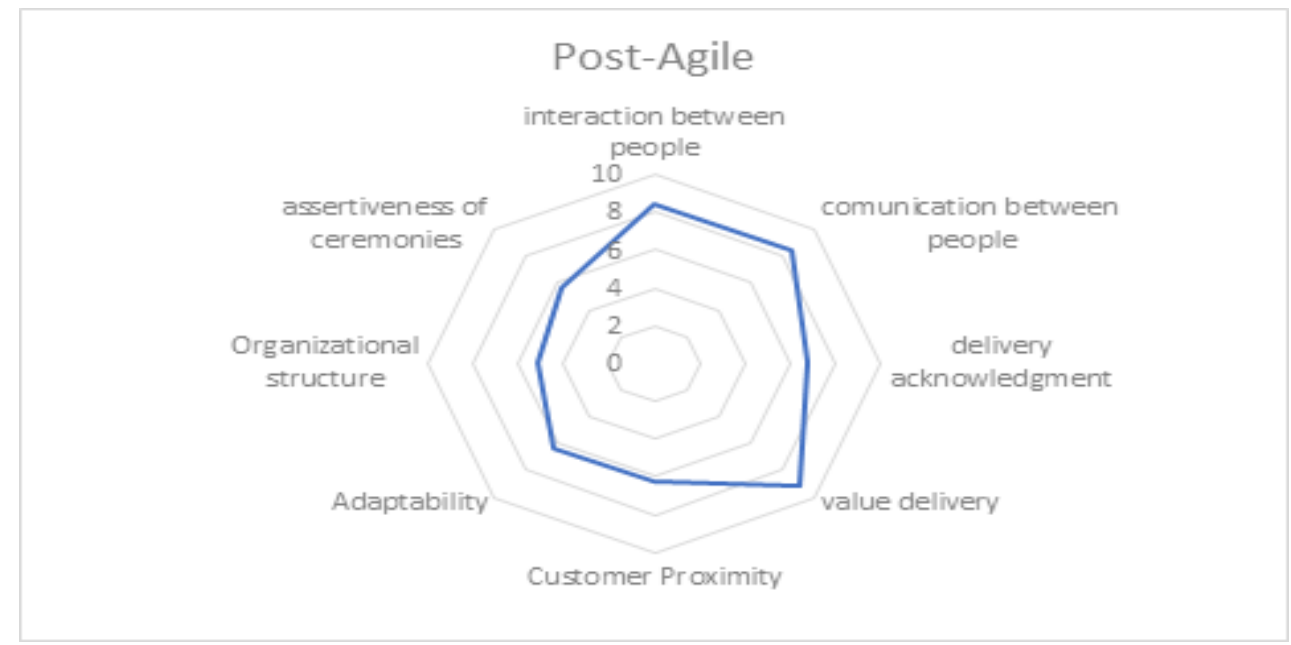

Figure 5. Knowledge about Scrum after the training program. Source: Researchers (Excel).

The post-workshop result from the learning and implementation of Scrum shows that the proximity, interaction and communication between the levels of people increased significantly, with emphasis on the effectiveness of meetings during implementation within the company's routine (assertiveness of events). Another relevant point to be highlighted was the increase in the effective delivery of value - although this point has been well developed before - and in the level of adaptability (responding to change) which also showed a significant increase.

In this initial analysis, it is possible to observe that the use of Scrum and the values contained in the Agile Manifesto (Beck. et. al., 2001) allowed a greater link between the teams of the projects, revealing that their interdependence exists, even though their activities and objectives are different. It is possible to affirm in this first general analysis that APM further strengthened the sense of collaboration between individuals, breaking the barriers of the activity until then sectorized, allowing people to interact and trust more with members of other teams and projects, in the same way that they trust the team members internally.

Also, it is possible to observe a decrease in the organizational structure, which means that, on average, the 14 participants broke with the work focused on departments to work in a model focused on the process, the way the leadership wanted before the intervention of the researchers.

Regarding the results of the questionnaire with binary answers, it is possible to observe what confirms the Agility values. All four values expressed in the Agile Manifesto (Beck et. al., 2001), showed positive variation on the influence on the unit of analysis. The interaction between people, effective value delivery, customer collaboration and change response varied positively. However, the Table 2 also reinforces the low adhering to the functions 
defined by the Scrum Master Guide (Scrum

Team) in the case studied.

Master, Product Owner, and Development

Table 2 - Parameters for using Scrum values and functions (in variation points)

\begin{tabular}{c|ccc}
\hline \multicolumn{1}{c}{ Scrum Values + Team Definition } & Before & After & Variation \\
\hline Individuals and interactions & 7.7 & 8.4 & +0.7 \\
Value delivery & 9.0 & 9.1 & +0.1 \\
Customer collaboration & 5.2 & 6.2 & +1.0 \\
Responding to change & 5.3 & 6.3 & +1.0 \\
Scrum Team & 5.7 & 5.1 & -0.6 \\
\hline
\end{tabular}

Source: Researchers.

Thereafter in relation to the use of the events determined by the Scrum Guide, the "prioritization of the task" varied positively in its direct application in the work routine at a substantial level (35.7\%). The application of time criteria to perform tasks (application sprints) showed no variation. Regarding Scrum
Events the positive variation was significant. When learning and using the tools present in the Scrum Guide there was a positive variation of $7.1 \%$ for Scrum Planning and $7.2 \%$ for Daily Scrum. However, the Scrum event most used in this case was Retrospective, with 35\% positive variance.

Table 3 - Parameters of ceremonies and Scrum artifacts (\%)

\begin{tabular}{|c|c|c|c|}
\hline Scrum events + artifacts & Before & After & Variation \\
\hline Scrum Planning (event) & $78,6 \%$ & $85,7 \%$ & $+7.1 \%$ \\
\hline Daily Scrum (event) & $71,4 \%$ & 78,6 & $+7.2 \%$ \\
\hline Retrospective (event) & $7,1 \%$ & $28,6 \%$ & $+21.5 \%$ \\
\hline Prioritization of tasks (artifacts) & $42,9 \%$ & $78,6 \%$ & $+35.7 \%$ \\
\hline Application of sprints (artifacts) & $78,6 \%$ & $78,6 \%$ & $+0 \%$ \\
\hline
\end{tabular}

Source: Researchers.

As a final analysis on the overall influence of Scrum processes and tools, according to the Scrum Guide, there was a positive variation in the perception and influence in the studied company of 0.8 points representing an increase of almost $20 \%$ in absolute terms. 
Table 4 - Scrum parameters deliver (general) and artifacts (\%)

\begin{tabular}{c|cccc}
\hline Overall classification & Before & After & Variation \\
\hline Scrum Effectiveness & 4,9 & 5,7 & +0.8 \\
\hline
\end{tabular}

Source: Researchers.

With the results obtained, the data from the questionnaire were resubmitted to the 14 participants of the organization in this research and the interviews were redone on January 8,2020 , to investigate the objectives achieved. Initially all participants interviewed were unanimous in saying that the relationship between people and the interaction between them in the workplace improved substantially. In other words, the APM were able to solve the problem described earlier of low communication between project teams. Also, the statement that with the improvement in the relationship in the organizational scope there was a reduction in resistance to change was unanimous once it was understood by the participants that frustration was innocuous when in fact the learning process in adaptation to changes was more valuable. And this was made clear with the use of Scrum ceremonies, especially in the use of the retrospective meeting after delivery cycles, in which the team can understand the process of the lessons learned from the period.

With the adoption of daily alignment meetings, there was a greater proximity between team members and leadership, which increased the dissemination of strategic guidelines in the tactical and operational scope of the projects. Consecutively, target dates and deadlines became better understood and respected, because each team member had a notion of why it is inserted in the project, increasing engagement and responsibility. The adoption of product backlogs increased the level of improvement of the prioritization of activities and tasks to be developed in the projects. Finally, the interviewees confirmed that there was no use of defined roles as stated in the Scrum Guide (it was not necessary to create the 3 roles).

Additionally, as a way of perpetuation of practices, the organization created an internal cycle of constant training, conducted by the human resources team, to disseminate and maintain the values and principles of APM and Scrum, in addition to generating new projects, such as the creation of a mobile application for a project of prospecting and customer loyalty of the mineral water treatment segment with Zeolite, a program of benefits to employees according to productivity and the creation of an internet video channel to disseminate knowledge about the products and services provided.

The improvement points allowed not only to achieve the objectives of productivity and engagement, but with the innovation of the products generated, the organization also managed to achieve market objectives by 
increasing its participation when prospecting customers, increasing revenue sustained with customer loyalty (new and old) and still competing in the market by providing new solutions for the same mineral compound, by creating multiple other product lines from previously used processes.

Finally it is important to highlight that some teams started using Kanban frames for backlog management and workflow maintenance and visibility in a completely spontaneous manner, because the training program focused on the use of Scrum tools. This can be considered as a "finding", as it demonstrates the effects of maintaining and reaffirming the values and pillars of the APM, which lead to greater autonomy of the teams to not only make daily decisions, but improving the search for management itself - a true process of continuous improvement.

Therefore it is possible to affirm that the use of APM is fully possible not only to generate new products or as a way to stimulate innovation, but also as a way to increase engagement and productivity while offering a more user-friendly, sociable and stable work environment.

\section{Final remarks}

As developed in this study, the data collected from the research allowed us to understand how the values of the Agile Manifesto and scrum tools could generate positive efficiency results in the routine of a
Brazilian mining industry. There were significant improvements in the work environment after the training program, with a total of 12 hours, for acknowledgement and application of the principles and values contained in the Agile Manifesto (Beck et. al., 2001) and scrum practices and techniques, confirming the literature on the subject, presented in this study (Amaral et. al., 2011; Dingsøyr, Nerur \& Balijepally, 2012; Sutherland \& Schwaber, 2017; Sabbagh, 2014; Eder, Conforto, Amaral \& Silva, 2015; Camargo \& Galegale, 2020). Through the CIMO logic of research protocol (Context, Intervention, Mechanisms and Results Obtained) this study was able to validate, through the capture of the participants' perceptions, the degree of evolution when the organization starts using the APM, applying questionnaires and interviews before and after the training program.

In general, there was variation in a positive perspective in the application of APM on the routines and processes of a company that does not participate in the traditional environment of adoption of the structure (Information Technology), confirming evidence presented by Conforto et. al. (2014), regarding the possibility of applying APM in addition to IT (industrial sector), not only in the sense of generating new products and services (innovation), but also as a way to improve project management, adjust the scope, meet requirements, improve communication 
and present results aligned with organizational strategy.

The fact that the 14 study participants learned and implemented Scrum in the company generated positive variations in regards to the relationship with people between different areas, between different teams, in the relationship with the customer, improvement in the process of delivery of values, improvement in communication and interactivity, increased productivity and creation of new products for the market (APM as a facilitator of innovation), such as mobile applications and creation of internal programs of benefits to employees according to productivity. The choice of these 14 participants was fundamental to maintain the application of Scrum in the routine and to disseminate knowledge to the other teams.

A spontaneous outcome was the implementation of the Kanban method for product backlog management, as a guarantor of visibility and workflow, even though the focus of the learning program was on Scrum implementation. This demonstrates the value of Scrum as a way to provide the autonomous search for continuous improvement and disclosure of spontaneous leaders (Camargo \& Galegale, 2020).

Therefore, still considering positive variances, it was observed that the strongest points where Scrum can influence the daily life of the selected company were the prioritization of tasks to be developed and the adoption of a retrospective meeting at the end of each delivery cycle. Both cases definitely increased the relationship and interaction between people, communication creation of new products and implementation of strategies in the tactical and operational scope. A single inconclusive point is the non-adoption of Scrum roles (the Product Owner, Scrum Master and the Development Team), because the comparison of questionnaires and interviews before and after training indicated that the organizational structure was horizontalized, which probably dispensed with the definition of specific roles, as provided in the Scrum Guide (Sutherland \& Schwaber, 2017).

Therefore, by this study it can be considered that the values contained in the Agile Manifesto (Beck et. al. 2001), and in the Scrum processes and tools based on the Scrum Guide (Sutherland \& Schwaber, 2017), influenced a company that is in the mining industry and in the processes and tools based on the Scrum Guide (industry, not belonging to the field of Technological Information). Thus, it is possible to affirm that the partial adoption of Scrum, adapted to the reality and scenario of the chosen company was absorbed, revealing new frontiers for the applicability of Scrum beyond IT, confirming the evidence of Conforto et al. (2014).

The main contribution of this study (technological product) is to offer elements for decision-making of project managers and dedicate to presenting the possibility of applying APM in an organization outside the 
IT sector. For the academy, it discussed the possibility of applying new management methodologies, which is relevant to the extent that there is a few studies that is dedicated on the results achieved in companies outside the IT sector.

It is recommended, as future studies, to analyze the level of Scrum adoption of other organizations outside the software development industry, as well as their correlations with the problems faced by companies in their daily management and the solutions suggested by Scrum. In addition, a longitudinal study of this same company after one year or more could show long-term results of the adoption of frequent retrospectives. On the other hand, as limitations this study was conducted through the level of perception of the 14 participants, which may eventually cause distortions about the applied reality due to the lack of understanding of one or more items pointed out during the research.

\section{References}

Alahyari, H., Berntsson Svensson, R, \& Gorschek, T (2017). A study of value in agile software development organizations. Journal of Systems and Software, v. 125, p. 271-288.

Amaral, D. C. et al. (2011). Agile project management: application in innovative products. São Paulo: Saraiva, p. 240.

Baccarini, D. (1996). The concept of project complexity - a review. International Journal of Project Management, v. 14, n. 4, p. 201204.
Bai, A., Mork, H. C., \& Stray, V. (2017). A cost-benefit analysis of accessibility testing in agile software development results from a multiple case study. Int. J. Adv. Softw, 10(1). Disponível em: https://www.duo.uio.no/handle/10852/7078 6.

Balasubramani, U. M., Iyer, K., Krishnan, B. S., \& Kovvuri, H. (2016). Bug Bash: An Efficient Approach to Increase Test Coverage and Ensure Product Quality in an Agile Environment. In 2016 IEEE International Symposium on Software Reliability Engineering Workshops (ISSREW) (pp. 29-36). IEEE. doi:10.1109/ISSREW.2016.16

Beck, K. (1999). Extreme Programming Explained: Embrace Change. AddisonWesley. United States.

Beck, K et al. (2001) Agile Manifesto. Available at <www.manifestoagil.com.br>. Accessed March 12, 2019.

Biancolino, C. A., Kniess, C., T; Maccari, A, \& Rabechini Junior, R. (2012). Protocol for the preparation of reports of technical production. Management and Projects Magazine. São Paulo, v. 3, n. 2, p 294-307, 2012.

Buchanan, J. (2008). Measuring up. PM Network. Project Management Institute.

Camargo, K., \& Galegale, N. (2020). Scrum Master and the exercise of leadership in agile software development teams: bibliometric analysis. Valore Journal, v. 5 , p. 151-162.

Cardozo, E. S. F. et al (2010). SCRUM and productivity in software projects: a systematic literature review. In: 14th International Conference on Evaluation and Assessment in Software Engineering (EASE). p. 1-4.

Catelli, A., \& Santos, E. S. (2001) Economic management of companies in the new economy. Vista \& Journal Accounting. Belo Horizonte, v. 12, $n^{\circ}$ 01. 2001. P 79-102. 
Conforto, E. C. et al (2014). Can agile project management be adopted by industries other than software development? Project Management Journal, v. 45, n. 3, p. 21-34.

Corrêa, H. L., \& Corrêa, C. A. (2012). Production and Operations Management. 3 ed. São Paulo: Atlas, 2012.

Deming, W. E. (1951). Elementary principles of the statistical control of quality. Nippon Kagaku Gijutsu Remmei, Tokyo.

Dingsøyr, T., Nerur, S., Balijepally, V., \& Moe, N. B. (2012). A decade of agile methodologies: Towards explaining agile software development.

Drucker, P. F. (1992). Managing for the future. São Paulo. Ed. Pioneira.

Ebsco Information Services (2020). Available at: https://www.ebsco.com/. Access at: October 1, 2020.

Eder, S., Conforto, E. C., Amaral, D. C., \& Silva, S. L. D. (2015). Differentiating traditional and agile approaches to project management. Production, 25(3), 482-497.

Gil, A. C. (2008). Social research methods and techniques. São Paulo, Atlas.

Highsmith, J. (2012). Agile Project Management. Ed. Alta Books, 2 ed., Rio de Janeiro.

Kruchten, P. (1996). Rational Development Process. In: Crosstalk: J. Defense Software Eng. Available in: www.stsc.hill.af.mil/crosstalk/frames.asp?ur $\mathrm{i}=1996 / 07 /$ rational.asp. Accessed: January 2020.

Larman, C, \& Basili, V. R. (2003). Iterative and incremental developments. a brief history. In: Computer, vol. 36, no. 6, pp. $47-$ 56, 2003. Available in: https://ieeexplore.ieee.org/abstract/documen t/1204375. Accessed January 2020.
Liker, J. (2004). O Toyota Way, McGraw-Hill, Nova Iorque.

Liker, J. K., \& Meier, D. (2007). Toyota Model: Application Manual. Porto Alegre: Bookman.

Maccormack, A. (2001) Product-Development Practices That Work. MIT Sloan Management Review. Vol. 42, N. 02. p. 75 84.

Maximiano, A. C. A. (2018) General theory of administration: from the urban revolution to the digital revolution. $8^{\mathrm{a}}$ Ed. Atlas. São Paulo.

Moraes, T., \& Ricco, A. (2020). Applicability of a web tool for aligning pmbok practices with scrum. Destarte, v. 9, n. 1, p. 58-76.

Nonaka, I, \& Takeuchi, H. (1986). The new new product development game. Harvard Business Review.

Ohno, T. (1997). The Toyota production system in addition to scale production. Translated by Cristina Schumacher. Porto Alegre. Ed. Bookman.

Project Management Institute. (2017). A Knowledge Guide for Managing Projects (PMBoK® Guide). (6a.). Newton Square, Pensilvânia: PMI - Project Management Institute.

Rad, P. F, \& Raghavan, A. (2000). Establishing an organizational project office. AACE International Transactions, ABI/INFORM Global, p. 13.

Rodriguez, P., Mendes, E., \& Turhan, B. (2018). Key stakeholders' value propositions for feature selection in software-intensive products: an industrial case study. IEEE Transactions on Software Engineering, p. 1-1.

Sambinelli, F., \& Borges, M. A. F. (2019). The Strategies to Increase Customer Value in Agile: A Survey of Brazilian Software Industry. Journal of Information Systems Engineering \& Management, v. 4, n. 2. 
Sanchez-Gordon, S., \& Luján-Mora, S. (2017). A method for accessibility testing of web applications in agile environments. In Proceedings of the 7th World Congress for Software Quality (WCSQ). In Press. (citado na página $13,15,85)$.

Sabbagh, R. (2018). Scrum - Agile

Management for Successful Projects. $1^{\text {a }}$ Edição. E-book. Open Acess. Ed. Casa do Código.

Schwaber, K, \& Sutherland, J. (2017). Scrum Guide. A Definitive Guide to Scrum: The Rules of the Game. Translation by Fábio Cruz, Eduardo Rodrigues Sucena. 2017. Open Acess. Available from: <https://www.scrum.org/resources/scrumguide?gclid=EAIaIQobChMI-ez7vjj4QIVhBCRCh2qqg9tEAAYASAAEgJ NOPD BwE>. Accessed October 2020.

Sliger, M., \& Broderick, S. (2008). The software project manager's bridge to agility. Addison-Wesley. United States.

Sutherland, J. (2004). Agile Development: Lessons Learned from the First Scrum. In: Agile Project Management Advisory
Service: Executive Update, volume 05, 2004. P 01-04.

Tiangtae, N., Ramingwong, S., Ramingwong, L., Potikanond, D., Homkong, N., \& Maneerat, N. (2017). Developing Software for the Deaf Community: Conquering an Extreme Case Scenario. In 2017 21st International Computer Science and Engineering Conference (ICSEC) (pp. 1-5). IEEE. VERSION ONE. 12th Annual State of Agile Report. 2018. Disponível em: http://stateofagile.versionone.com.

Vacari, Isaque (2015). An empirical study on the adoption of agile methods for software development in public organizations. Master of science thesis. Pontifícia Universidade Católica do Rio Grande do Sul.

Versionone. (2020). 14th Annual State of Agile Report: the state of agile development. Available in: https://stateofagile.com/\#ufh-i-61570609814th-annual-state-of-agile-report/7027494. Accessed: October 2020.

Werkema, M. C. (1995). The quality tools in process management. 4 Ed. Belo Horizonte. FCO. 
ANNEX 01 - Questionnaire to measure the perception of scrum evolution before and after the study

\begin{tabular}{|c|c|c|}
\hline Question & Answers & Analysis \\
\hline $\begin{array}{l}1 \text { - How effective do you believe that interactions between people } \\
\text { are? }\end{array}$ & $\begin{array}{l}\text { 1pt - ineffective / } \\
\text { 10pts - very effective. }\end{array}$ & Agile values \\
\hline $\begin{array}{l}2 \text { - How much do you believe communication between people is } \\
\text { effective? }\end{array}$ & $\begin{array}{l}1 \mathrm{pt}-\text { ineffective } / \\
10 \mathrm{pts}-\text { very effective. }\end{array}$ & Agile values \\
\hline $\begin{array}{l}3 \text { - How much do you believe your work is recognized when } \\
\text { delivered? }\end{array}$ & $\begin{array}{l}1 \mathrm{pt}-\text { ineffective / } \\
\text { 10pts - very effective. }\end{array}$ & Agile values \\
\hline $\begin{array}{l}4 \text { - How much do you believe your work adds value to the entire } \\
\text { company? }\end{array}$ & $\begin{array}{l}1 \mathrm{pt}-\text { ineffective / } \\
10 \mathrm{pts}-\text { very effective. }\end{array}$ & Agile Values \\
\hline $\begin{array}{l}5 \text { - How much do you believe that the customer participates in the } \\
\text { company's projects/products/services? }\end{array}$ & $\begin{array}{l}1 \mathrm{pt}-\text { ineffective } / \\
10 \mathrm{pts}-\text { very effective. }\end{array}$ & Agile values \\
\hline $\begin{array}{l}6 \text { - How much do you believe that your company is prepared to adapt } \\
\text { to the market or change the route of a process/project? }\end{array}$ & $\begin{array}{l}1 \mathrm{pt}-\text { ineffective / } \\
10 \mathrm{pts}-\text { very effective. }\end{array}$ & Agile values \\
\hline $\begin{array}{l}7 \text { - How much is the hierarchical structure of the company more } \\
\text { vertical (with traditional managers) or more horizontal (each group / } \\
\text { team / self-organized sector)? }\end{array}$ & $\begin{array}{l}1 \mathrm{pt}-\text { ineffective / } \\
\text { 10pts - very effective. }\end{array}$ & Agile values \\
\hline $\begin{array}{l}8 \text { - Does the company have a project/product/service planning } \\
\text { meeting? }\end{array}$ & Just yes or no. & Scrum tools \\
\hline $\begin{array}{l}9 \text { - Does the company have periodic meetings of task alignment and } \\
\text { realignment (Daily Scrum)? }\end{array}$ & Just yes or no. & Scrum tools \\
\hline $\begin{array}{l}10 \text { - At the end of certain periods, does the company have } \\
\text { "retrospective" meetings? }\end{array}$ & Just yes or no. & Scrum tools \\
\hline $\begin{array}{l}11 \text { - How effective is your company in planning meetings, daily } \\
\text { meetings and "retrospective" meetings? }\end{array}$ & $\begin{array}{l}1 \mathrm{pt}-\text { ineffective / } \\
\text { 10pts - very effective. }\end{array}$ & Scrum tools \\
\hline 12 - Does your company generally prioritize activities? & Just yes or no. & Scrum tools \\
\hline 13 - Does your company work with Sprints? & Just yes or no. & Scrum tools \\
\hline
\end{tabular}

Source: Researchers. 
Soueid, M. I., \& Martins, A. F. C. (2021, Ed. Esp. jan./abr.). Scrum and agility beyond it: evidences in the brazilian mining industry

ANNEX 02 - Descriptive statistics of perception notes before and after learning Scrum

\begin{tabular}{|l|r|r|r|r|r|}
\hline \multicolumn{1}{|c|}{ 'Before Scrum } & N & Minimum & Maximum & Average & Std. Bypass \\
\hline $\begin{array}{l}\text { Interaction between people } \\
\text { (1 to 10) }\end{array}$ & 14 & 5,0 & 10,0 & 7,786 & 1,8051 \\
\hline $\begin{array}{l}\text { Communication between } \\
\text { people (1 to 10) }\end{array}$ & 14 & 5,0 & 10,0 & 7,857 & 2,0327 \\
\hline $\begin{array}{l}\text { Delivery Recognition (1 to } \\
\text { 10) }\end{array}$ & 14 & 1,0 & 10,0 & 7,429 & 2,5333 \\
\hline $\begin{array}{l}\text { Value Delivery (1 to 10) } \\
\text { Customer proximity (1 to }\end{array}$ & 14 & 7,0 & 10,0 & 9,000 & 1,1094 \\
\hline $\begin{array}{l}\text { 10) } \\
\text { Adaptability to change (1 to }\end{array}$ & 14 & 1,00 & 9,00 & 5,2143 & 2,35922 \\
\hline $\begin{array}{l}\text { Organizational structure - } \\
\text { Scrum Team (1 to 10) }\end{array}$ & 14 & 1,00 & 9,00 & 5,3571 & 2,27384 \\
\hline $\begin{array}{l}\text { Scrum assertiveness (1 to } \\
10)\end{array}$ & 14 & 1,00 & 9,00 & 4,9286 & 2,49505 \\
\hline \begin{tabular}{l} 
Valid N (listwise) \\
\hline
\end{tabular} & & & & & \\
\hline
\end{tabular}

\begin{tabular}{|l|r|r|r|r|r|}
\hline \multicolumn{1}{|c|}{ After Scrum } & \multicolumn{1}{|c|}{ N } & \multicolumn{1}{c|}{ Minimum } & \multicolumn{1}{c|}{ Maximum } & \multicolumn{1}{c|}{ Average } & \multicolumn{1}{|c|}{ Std. Bypass } \\
\hline $\begin{array}{l}\text { Interaction between people } \\
\text { (1 to 10) }\end{array}$ & 14 & 4,0 & 10,0 & 8,429 & 2,0273 \\
\hline $\begin{array}{l}\text { Communication between } \\
\text { people (1 to 10) }\end{array}$ & 14 & 4,0 & 10,0 & 8,571 & 2,1018 \\
\hline $\begin{array}{l}\text { Delivery Recognition (1 to } \\
\text { 10) }\end{array}$ & 14 & 1,0 & 10,0 & 6,786 & 3,1666 \\
\hline Value Delivery (1 to 10) & 14 & 7,0 & 10,0 & 9,143 &, 9493 \\
\hline $\begin{array}{l}\text { Customer proximity (1 to } \\
10)\end{array}$ & 14 & 1,00 & 9,00 & 6,2143 & 2,80600 \\
\hline $\begin{array}{l}\text { Adaptability to change (1 to } \\
\text { 10) }\end{array}$ & 14 & 1,00 & 10,00 & 6,3571 & 2,56026 \\
\hline $\begin{array}{l}\text { Organizational structure - } \\
\text { Scrum Team (1 to 10) }\end{array}$ & 14 & 1,00 & 9,00 & 5,1429 & 2,62699 \\
\hline $\begin{array}{l}\text { Scrum assertiveness (1 to } \\
\text { 10) }\end{array}$ & 14 & 1,00 & 10,00 & 5,7143 & 2,16364 \\
\hline Valid N (listwise) & 14 & & & & \\
\hline
\end{tabular}

Source: Researchers (SPSS, version 15.0). 
Soueid, M. I., \& Martins, A. F. C. (2021, Ed. Esp. jan./abr.). Scrum and agility beyond it: evidences in the brazilian mining industry

ANNEX 03 - Graphs for the issues contained in Annex 01

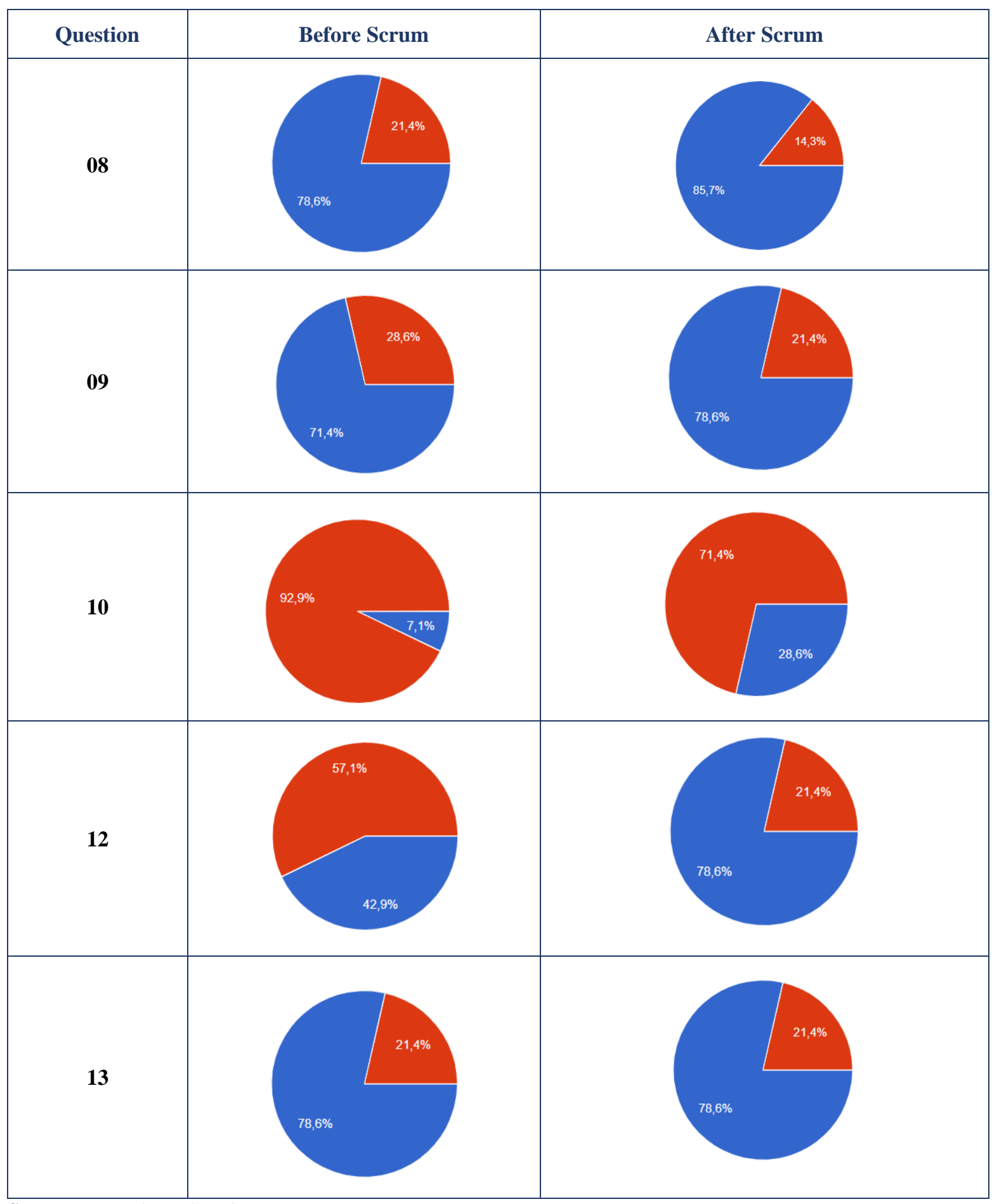

Source: Researchers (Google Forms). 